\section{Chronic Transplacental Haemorrhage Causing Acute Fetal Distress}

British Medical fournal, 1970, 2, 218

Massive feto-maternal haemorrhage has been well recognized for some years as a not uncommon cause of severe anaemia in the neonate (Chown, 1954; Cohen et al., 1964), and since Kleihauer et al. (1957) introduced the acid elution treatment of maternal blood films detection of fetal cells in maternal blood has become a relatively simple procedure.

The following report is of a case of chronic feto-maternal haemorrhage of severity sufficient to require urgent delivery and treatment of the infant.

\section{CASE REPORT}

The mother, a 19-year-old primigravida, had an uneventful antenatal course. Her blood group was $\mathrm{A} R \mathrm{R}$ (D) positive and she had no atypical antibodies. Fetal size, however, was noted to be gradually falling behind her dates in the third trimester, and the possibility of intrauterine fetal growth retardation was considered, though she was normotensive and continued to gain weight.

Spontaneous labour occurred at term and progressed normally for nine hours. The fetal heart rate became irregular and continued to deteriorate after 12 hours, varying from 80 to 160 between contractions. Rupture of the membranes produced thickly meconiumstained liquor. Immediate delivery was therefore induced within five minutes by means of the $50-\mathrm{mm}$. vacuum extractor, though the cervix was dilated only $7 \mathrm{~cm}$.

The male child was noted to be very pale immediately after birth. Resuscitation was carried out by oropharyngeal suction, intranasal oxygen, and intravenous nalorphine. The first breath was at one and a half minutes, and respirations of a rather grunting nature were established at two minutes. Apgar score at one minute was 6 , rising to 9 at five minutes.

An umbilical vein catheter was inserted and blood samples were taken for examination with the following results: haemoglobin 4.6 g. $/ 100$ ml., P.C.V. $19 \%$, M.C.H.C. $24 \%$, group A Rh (D) positive, direct Coombs test negative. Blood film showed a bizarre picture, with pronounced hypochromasia, fragmented and Burr type cells, and many nucleated red blood cells. Blood urea (to exclude haemolytic uraemic syndrome) was $8 \mathrm{mg} . / 100 \mathrm{ml}$.

Clinically the chest was clear and the heart was not enlarged. There was no peripheral oedema. The liver was enlarged $2-3 \mathrm{~cm}$. below the right costal margin and the spleen was just palpable.

Forty milligrams of blood was removed from the umbilical vein, $120 \mathrm{ml}$. of packed red cells, homologous to $\mathrm{ABO}$ and $\mathrm{Rh}$ type, was transfused at a rate of $30 \mathrm{ml}$./hour, and prophylactic digitalization was begun (1 mg. intramuscularly twice daily). Intramuscular frusemide was also given. Pronounced improvement in the infant's condition resulted.
The following day the baby was tachypnoeic and bilateral crepitations were audible, with a short-grade $2 / 4$ systolic murmur maximal down the left sternal edge. Chest $x$-ray examination showed a greatly enlarged heart. Intramuscular digoxin was continued. The haemoglobin was 13.6 g. $/ 100 \mathrm{ml}$. and the P.C.V. $47 \%$.

On the third day pitting oedema of the lower legs and feet was noted, but the heart had returned to normal size. Digoxin was stopped. Over the next few days the oedema disappeared and subsequent progress was uneventful. Further investigations showed: Venereal Disease Research Laboratory test negative; serum iron 28 $\mu \mathrm{g} . / 100 \mathrm{ml}$. (normal $60-70 \mu \mathrm{g} . / 100 \mathrm{ml}$.); and total plasma proteins $4.4 \mathrm{~g} . / 100 \mathrm{ml}$. (albumin $2.2 \mathrm{~g}$., globulin $2.2 \mathrm{~g}$.). On the eleventh day the infant's haemoglobin was $16 \mathrm{~g} . / 100 \mathrm{ml}$. and the blood film showed a few normoblasts.

The placenta weighed $560 \mathrm{~g}$. and measured 16 by 13 by $2.5 \mathrm{~cm}$. It was pale and gritty, with membranes green but normal. The umbilical cord was $35 \mathrm{~cm}$. long, with a true knot $6 \mathrm{~cm}$. from the cut end. Of the three vessels present two were surrounded by haematoma. Microscopically parts of the placenta were quite densely calcified. The structure of the villi was not that usually seen at term, being quite large, very congested, and with syncytial knots present but not conspicuous.

Maternal blood was examined on the day after delivery. Haemoglobin electrophoresis was normal, but the acid elution method showed $6 \%$ of the cells to be fetal in origin. A blood sample collected from the mother six days antepartum was still available, and Kleihauer elution of this sample yielded a fetal cell count of $9 \%$-equivalent to some $350 \mathrm{ml}$. of fetal blood, which obviously represents feto-maternal bleeding of a chronic nature.

\section{CONCLUSION}

There can be little doubt that feto-maternal haemorrhage is a not uncommon cause of neonatal anaemia. It would therefore seem reasonable to suggest that a search for fetal cells in the maternal circulation should be made whenever an infant is born anaemic without obvious blood loss. Maternal blood should be sampled as soon after delivery as possible, before any existing blood group incompatibility removes the fetal cells from her circulation.

Chown, B. (1954). Lancet, 1, 1213.

\section{REFERENCES}

Cohen, F., Zuelzer, W. W., Gustafson, D. C., and Evans, M. M. (1964). Blood, 23, 621 .

Kleihauer, E., Braun, H., and Betke, K. (1957). Klinische Wochenschrift, 35,637 .

G. G. LUNAY, F.A.I.M.L.T., F.A.C.M.T.

R. F. EDWARDS, M.B., B.S.

D. B. THOMAS, ${ }^{*}$ M.B., B.S.

King Edward Memorial Hospital for Women, Subiaco, Western Australia.

*Present address : Princess Margaret Hospital, Perth, W.A. 